\title{
Proliferating Cell Nuclear Antigen Expression in the Survival of Astrocytoma Patients
}

\author{
L.C. Ang, M. Plewes, L. Tan, H. Begley, A. Agranovich and D. Shul
}

\begin{abstract}
The PC10, a monoclonal antibody against proliferating cell nuclear antigen (PCNA), is known to show immunoreactivity in routinely processed paraffin embedded tissue. This antibody was applied to 72 astrocytic tumours from surgical biopsy material obtained in a ten year period. The PCNA labelling index (LI) obtained by image analysis was compared with patient's survival, age at diagnosis, and Karnofsky score as well as the histological grade of tumour. The survival analysis shows that patients with tumour PCNA LI of more than 6\% have significantly poorer prognosis than those with 6\% and below. In addition, there is also good correlation between PCNA LI with age, Karnofsky and tumour grade. This study suggests that although the PCNA expression of astrocytoma could be a useful predictor of patient's outcome, it is not an independent prognostic factor but has derived its statistical association with survival secondarily through its relationship with tumour grade, age and Karnofsky score.
\end{abstract}

\begin{abstract}
Résumé: Expression de l'antigène nucléaire des cellules en prolifération comme prédicteur de la survie chez les patients atteints d'astrocytome. Le PCl0, un anticorps monoclonal dirigé contre l'antigène nucléaire des cellules en prolifération (PCNA) démontre une immunoréactivité dans les tissus inclus dans la paraffine par la technique de routine. Cet anticorps a été appliqué à 72 tumeurs astrocytaires provenant de biopsies chirurgicales obtenues sur une période de dix ans. L'indice de marquage par le PCNA obtenu pas analyse d'image a été analysé en fonction de la survie des patients, à l'âge au moment du diagnostic, au score de Karnofsky et au stade de la tumeur. L'analyse de survie montre que les patients ayant un indice de plus de $6 \%$ ont un pronostic significativement plus sombre que ceux dont l'indice est de $6 \%$ ou moins. De plus, il existe également une bonne corrélation entre l'indice de marquage par le PCNA et l'âge, le score de Karnofsky et le stade de la tumeur. Cette étude suggère que, bien que l'expression du PCNA de l'astrocytome puisse être un porédicteur utile du devenir du patient, ce n'est pas un facteur pronostique indépendant parce que son association statistique avec la survie est secondaire à sa relation avec le stade de la tumeur, l'âge et le score de Karnofsky.
\end{abstract}

Can. J. Neurol. Sci. 1994; 21: 306-310

Tumours of astrocytic lineage are the most common primary neoplasm of the central nervous system. The histological grading is considered as an important factor in predicting the outcome of patients with such tumours. But there are various systems used in grading these tumours rendering comparisons between different treatment centres very difficult. ${ }^{1-5}$ Even if one uniform system is used in grading, the results could be very subjective depending on the experience and training of individual pathologists. Because of these reasons, various markers of cellular proliferative activities are introduced with the hope of grading these tumours more objectively. The PC10 a monoclonal antibody against proliferating cell nuclear antigen (PCNA) could be successfully applied to various tumour tissues, including archival material, which have been already fixed in formalin and then embedded in paraffin. ${ }^{6}$

PCNA, an auxiliary protein of DNA-delta-polymerase at the site of DNA replication during cell cycle, attains the highest concentration during the proliferative phases of the cycle. ${ }^{7-10}$ PCNA expression in a number of tumours such as gastric carcinoma, gut lymphoma and haemangiopericytoma has also been linked to the prognostic outcome of such tumours. ${ }^{11-13} \mathrm{~A}$ handful of previous reports have also studied the correlation of PCNA LI (labelling index) with the grades of astrocytoma but these results appeared rather conflicting. ${ }^{14-16}$ Only one other study with smaller number of astrocytomas (42 cases) has looked into the correlation of PCNA LI and survival of astrocytoma patients. ${ }^{17}$ In the present study we examine the correlation of PCNA LI

From the Department of Pathology, Sunnybrook Health Science Centre, University of Toronto, Toronto (L.C.A., H.B.); the Department of Pathology, Royal University Hospital and University of Saskatchewan, Saskatoon (M.P.. D.S.): the Department of Community Health and Epidemiology, and University of Saskatchewan, Saskatoon (L.T.): the Department of Radiational Oncology. University of Saskatchewan and Saskatoon Cancer Clinic, Saskatoon (A.A.).

RECEIVED FEBRUARY 18, 1994. ACCEPTED IN FINAL. FORM JUNE 3, 1994

Reprint requests to: Dr. L.C. Ang, Department of Pathology (Neuropathology), University of Toronto. Sunnybrook Health Science Centre, 2075 Bayview Avenue, North York, Ontario, Canada M4N 3M5 
with astrocytoma patients' survival and 3 other prognostic factors namely. 1) age at diagnosis, 2) histological grade and 3) Karnofsky score. ${ }^{18}$ A program using the IBAS image analysis system was designed to measure the PCNA LI in order to obtain more objective results.

\section{Materials and Methods}

A total of 72 cases of astrocytoma including glioblastoma multiforme were identified from the surgical biopsy files of the Royal University Hospital of Saskatoon through the period of 1 July 1980 to 30 June 1990 . All these cases had sufficient material for PC10 immunohistochemistry and were fixed in $4 \%$ buffered formaldehyde for approximately 24 hours before processing. These 72 tumours were reviewed and graded histologically using the method proposed by Daumas-Duport and divided into Grade II (12 cases), Grade III (14 cases) and Grade IV (46 cases). ${ }^{5}$ This method is based upon the presence or absence of four morphological criteria: nuclear atypia, mitoses, endothelial proliferation and tumour necrosis. The summary score for a tumour is translated into a grade as follows: 0 criteria $=$ grade $\mathbf{I}$, 1 criterion $=$ grade II, 2 criteria $=$ grade III, 3 or 4 criteria $=$ grade IV. We had also excluded cases with diagnoses of juvenile pilocytic astrocytoma, optic glioma, subependymal giant cell astrocytoma, pleomorphic xanthoastrocytoma, ganglioglioma and mixed glioma with a prominent oligodendrogliomatous component. All these types of primary glial tumours were excluded because they have distinct pathological features and different biological behaviour compared to the ordinary astrocytoma.

Formalin-fixed, paraffin-embedded blocks of tumour tissue were cut at $6 \mu \mathrm{m}$, attached to coated slides (3 - aminopropyltriethoxy-silane - Sigma), blotted, and air dried overnight at room temperature. These slides were hydrated and washed in PBS.

Non-specific background staining was reduced by the application of $20 \%$ normal horse serum. The sections were incubated overnight at $4^{\circ} \mathrm{C}$ with monoclonal anti-PCNA antibody (clone PC10-Novocastra Laboratories Ltd., Newcastle-upon-Tyne, UK) diluted 1:200. The specificity of this antibody to PCNA in vertebrate species has been established in Western blot, immunoprecipitation and enzyme-linked immunosorbent assays (ELISA). Slides were washed in PBS, then incubated 60 minutes at room temperature with biotinylated anti-mouse IgG 1:225 (Vector Laboratories). Endogenous peroxidase activity was blocked with $3 \% \mathrm{H}_{2} \mathrm{O}_{2}$ /methanol. After a PBS wash the slides were then incubated 60 minutes with Vectastain $A B C$ reagent (Vector Laboratories) at room temperature. Following a PBS wash, the color was developed using $0.03 \%$ diaminobenzidine (Sigma), $0.01 \mathrm{M}$ imidazole ( $\mathrm{pH}$ 7.4) (Boehringer Mannheim), and $0.018 \% \mathrm{H}_{2} \mathrm{O}_{2}$ in $0.05 \mathrm{M}$ Tris buffer ( $\mathrm{pH}$ 7.6). The sections were then treated with $2 \%$ osmium tetroxide for 10 minutes, washed in water and counterstained with $1 \%$ methyl green. For positive controls specimens of tonsils resected surgically were used and normal cerebral cortices were the negative control.

The PCNA immunostained sections of the tumours were examined qualitatively under the light microscope (L.C.A) and areas (non-hemorrhagic and non-necrotic) with highest concentration of positive nuclei were selected for image analysis. The morphometric measurements were performed (H.B.) with the
IBAS system (Kontron Electronik, Germany) utilizing an Axioplan microscope (Zeiss, West Germany) and a MTI camera (Dage-MT1 Inc., USA). Images of each tumour at 200x magnification were captured on the computer screen and subsequently processed by scaling the grey level distribution with 0 representing the darkest and 255 representing the lightest level. Grey levels $(0$ to 95$)$ were selected to enhance all the nuclei in the field and then the nuclei were discriminated and counted. Lower grey levels ( 0 to 73 ) were selected to enhance only the PCNA stained nuclei which were also discriminated and counted. In each case at least 500 nuclei (mean 850 ) were counted and the PCNA LI was calculated as a percentage of positively stained nuclei over the total number of tumour cell nuclei counted. . $^{14-17}$

The clinical data from these 72 cases were obtained from the medical records of the Saskatoon Cancer Clinic and Royal University Hospital of Saskatoon. The data examined in this study included age at diagnosis, sex, Karnofsky score at admission, presenting symptoms, location of tumours, and survival. The age distribution of the various patients with the different grades of astrocytoma is shown in the Table. All patients were followed up for a minimum of two years with the longest follow-up being 9 years.

\begin{tabular}{|c|c|c|c|c|}
\hline $\begin{array}{l}\text { Age Group } \\
\text { (Years) }\end{array}$ & Grade II & Grade III & Grade IV & $\begin{array}{c}\text { Total } \\
\text { Number }\end{array}$ \\
\hline$<10$ & 3 & 1 & 0 & 4 \\
\hline $10-19$ & 1 & 0 & 2 & 3 \\
\hline $20-29$ & 1 & 1 & 0 & 2 \\
\hline $30-39$ & 3 & 3 & 1 & 7 \\
\hline $40-49$ & 3 & 2 & 2 & 7 \\
\hline $50-59$ & 0 & 3 & 13 & 16 \\
\hline$>=60$ & 1 & 4 & 28 & 33 \\
\hline
\end{tabular}

\section{RESULTS}

As previously reported the PC 10 immunostaining in the nuclei of tumour cells could be either diffuse, granular or mixture of both. ${ }^{6,14-17}$ The staining intensity is also highly variable and there is marked regional variation in the distribution of immunostaining within the same tumour. ${ }^{6}$ The range of PCNA LI in this study is between $0.2 \%$ to $61 \%$. Examples of immunoreactivity in grade II, grade III and grade IV astrocytoma are shown in Figure 1 (a, b and c).

The mean PCNA LI for patients diagnosed with Grade II, Grade III and Grade IV astrocytoma are $3.17 \% \pm 0.81$ (SEM), $9.71 \% \pm 2.47$ (SEM) and $18.01 \% \pm 1.98$ (SEM) respectively. Hence, the higher grade tumours tend to have higher labelling index. A scattergram of the relationship between tumour grade and PCNA LI with the regression line drawn in shows significant correlation with coefficient of correlation of +0.452 which is statistically significant $(P<0.001)$ (Figure 2 ).

The survival after diagnosis of patients with PCNA LI of tumour above $6 \%$ (46 patients) is compared to the group of 


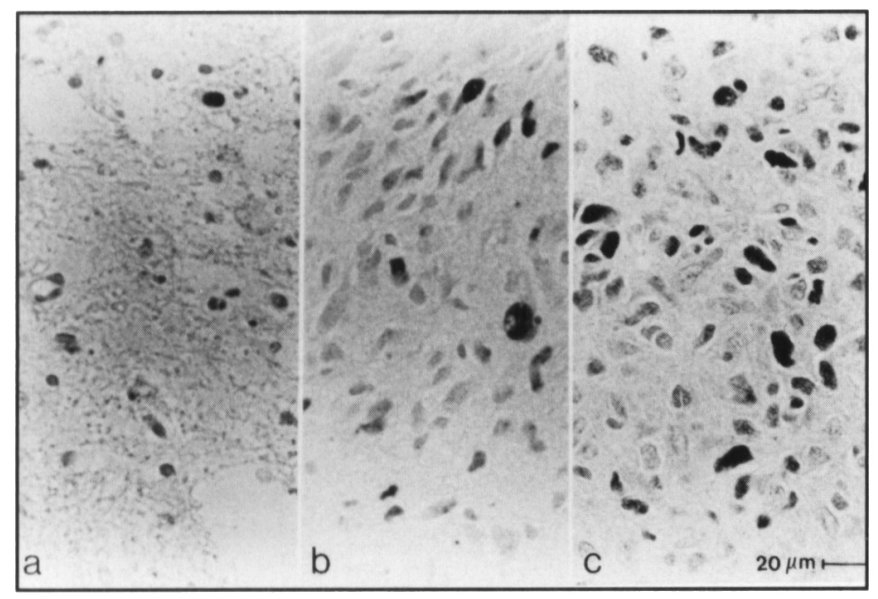

Figure 1: PCNA immunoreactivity in a) astrocytoma (grade II), b) anaplastic astrocytoma (grade III) and c) glioblastoma multiforme (grade IV). There is an increase in proportion of tumour cells with nuclear staining as the histological grade increases. PClO with methyl green counterstain.

patients with $6 \%$ or less (26 patients) (Figure 3). The difference in survival between these 2 groups is highly significant statistically $(\mathrm{P}<0.0001)$. The median survival for patients with PCNA LI more than $6 \%$ is about 5 months compared to 6 years (73 months) in those with $6 \%$ or less. In the first group none of the patients were alive at the time of study and in the second group more than $35 \%$ were alive. Apparently, PCNA LI is a good predictor of patients' outcome.

The coefficient of correlation between PCNA LI and age of patients at time of diagnosis is +0.40 which is statistically significant $(\mathrm{P}<0.001)$. The significant positive coefficient of correlations suggests that PCNA LI tends to increase in tumours from older patients. There is also significant negative coefficient of correlation $-0.336(p<0.004)$ which suggests that PCNA LI tends to decrease with increasing Karnofsky score. A comparison of PCNA LI for tumours arising from various anatomical sites such as the different lobes, thalamus, basal ganglia, brain stem, cerebellum etc. was not done because these tumours happened to fall into too numerous categories according to sites resulting in very small numbers in each category, making valid analysis not feasible.

Using the Cox Proportional Hazard model for univariate survival analysis which displays the degree of association between each of 5 factors (PCNA LI, age, histological grade, Karnofsky score and sex) and patients' survival, the results are expressed as approximate chi-square to enter or remove and its p-value. As shown in Figure 4, the histological grading using the Daumas-Dupont criteria is the most significant prognostic factor, followed by age, then Karnofsky, and then the PCNA LI. ${ }^{5}$ Based on the multivariate approach with the Cox Proportional Hazard model, we found that once histological grade, age and Karnofsky have been entered into the survival model, PCNA LI is no longer a significant additional prognostic factor.

\section{Discussion}

According to Bravo and MacDonald-Bravo there are at least two forms of PCNA antigens; a soluble form, not involved in cell proliferation and an insoluble form associated with cell proliferation including DNA replication. ${ }^{7.8}$ The $\mathrm{PC} 10$ monoclonal antibody when used on formalin-fixed normal tissue is supposed to label only the form associated with cell proliferation. ${ }^{6}$ But it is also quite obvious that in some neoplasms such as breast and

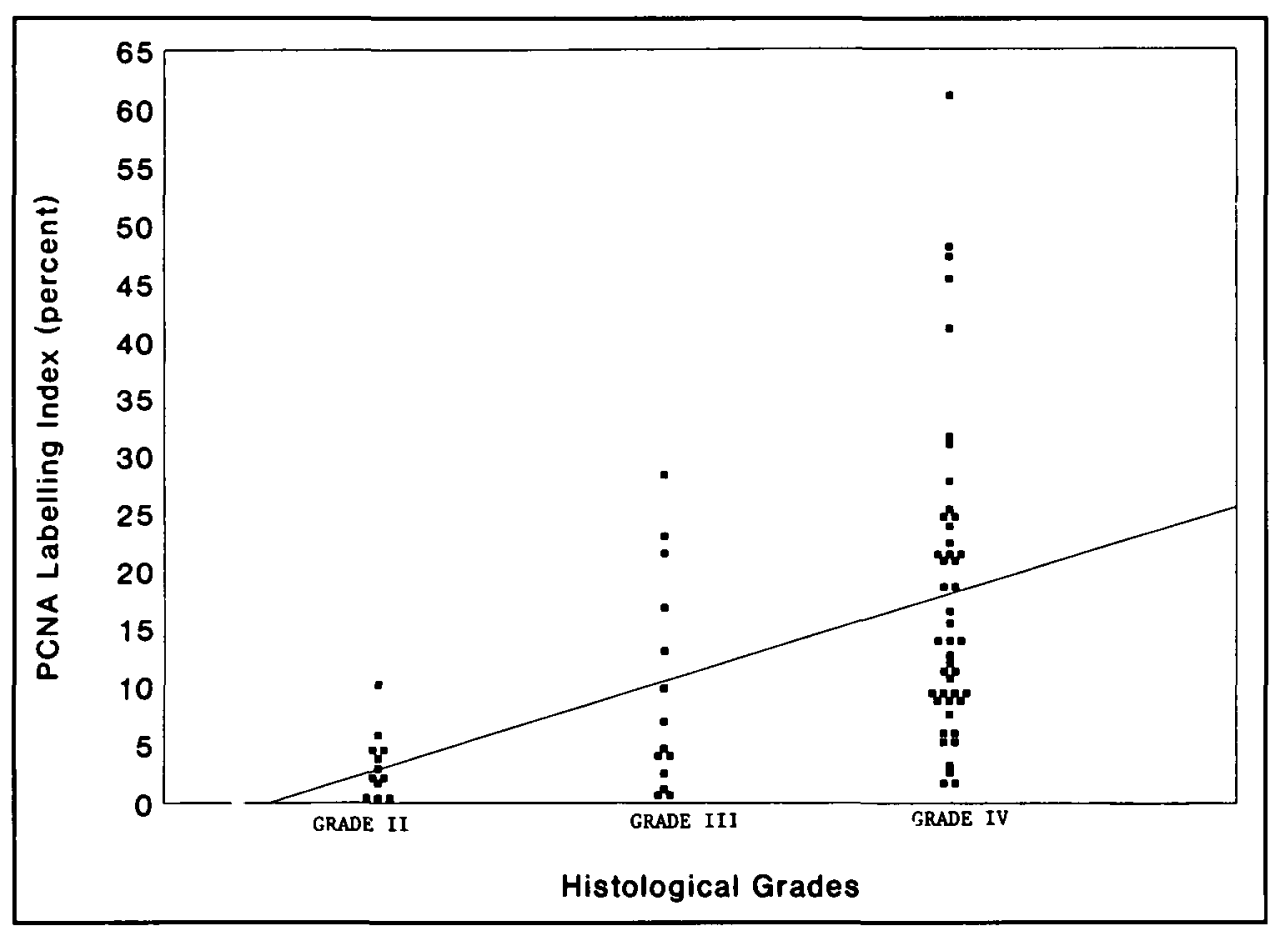

Figure 2: Scattergram of relationship between tumour grade and PCNA LI with the regression line drawn in showing significant positive correlation with coefficient of correlation of $+0.452(p<0.001)$. 


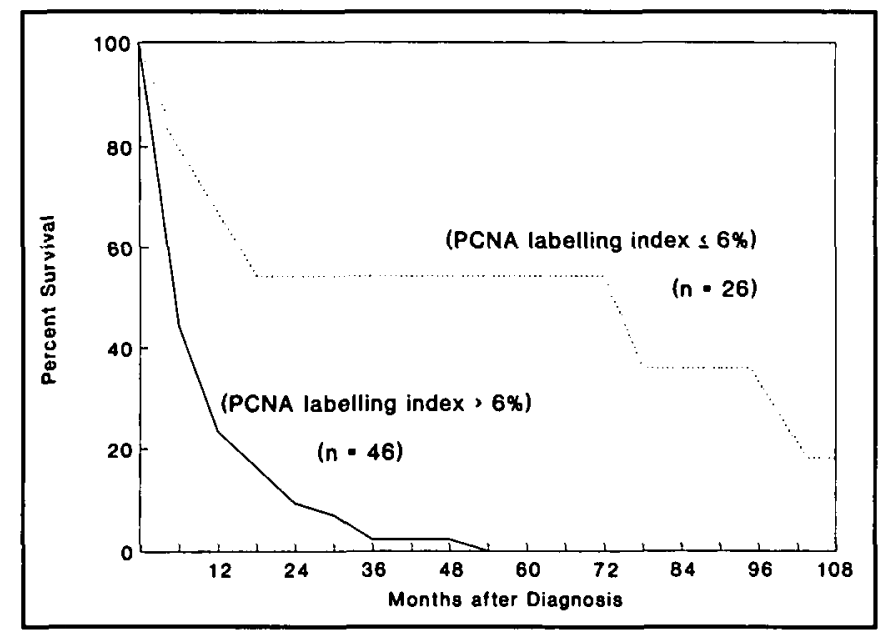

Figure 3: The survival of patients with PCNA LI of tumours above 6\% is significantly lower than those with PCNA LI of $6 \%$ and below $(p$ $<0.0001)$.

\begin{tabular}{|lcc|}
\hline \multicolumn{3}{|c|}{$\begin{array}{c}\text { Statistical Analysis: } \\
\text { variables in Cox Proportional Hazards Model }\end{array}$} \\
\hline \multicolumn{3}{c}{$\begin{array}{c}\text { Approximate } \\
\text { Chi-quare }\end{array}$} \\
\hline Survival vs: & 38.88 & p-value \\
\hline Grade & 33.73 & $<0.0001$ \\
Age & 17.39 & $<0.0001$ \\
Karnofsky & 16.73 & $<0.0001$ \\
PCNA & 3.54 & $<0.0001$ \\
Sex & & 0.06 \\
& &
\end{tabular}

Figure 4: Univariate using the Cox Proportional Hazard Model analysis showing the degree of association between each of the 5 factors i.e. PCNA LI, age of patient, histological grade, Karnofsky score and sex with survival of patients express as approximate chi-square and p-value.

gastric carcinoma the relationship between PCNA expression and S-phase function is lost and the PCNA LI obtained is higher than expected from S-phase fraction determination by flow cytometry. ${ }^{6}$ There is at least evidence from few studies that showed PCNA is being expressed not only in S-phase but also G-I and M-phase. To further complicate matters, it has been found that growth factors such as platelet derived growth factors, fibroblast and epidermal growth factors could also increase PCNA expression through autocrine or paracrine stimulation. ${ }^{19-21}$ It is very likely that high grade astrocytoma especially glioblastoma has various growth factor receptors that could enhance PCNA expression. ${ }^{22-25}$ Nevertheless, while all these factors could affect PCNA expression, its labelling index has been shown to correlate with proliferative activities and even outcome in some type of tumours such as non-Hodgkin lymphoma, gastric carcinoma, primary gastrointestinal lymphoma, haemangiopericytoma, acute leukaemia and non-small cell lung carcinoma. ${ }^{6.11-13.26 .27}$ Moreover, PCNA LI was also found to have good correlations in some tumours with the expression of other markers of cell proliferation such as, $3[\mathrm{H}]$-thymidine, Ki-67, bromodeoxyuridine (BrdU), DNA polymerase-alpha and silver stained nuclear organizer regions. ${ }^{6,28-31}$
Although PC10 has been shown to be useful for studies on archival tissue embedded in paraffin, the interpretation of the results may be affected by duration of formalin fixation and the heterogeneity in the immunoreactivity. ${ }^{6}$ The fact that the PCNA immunostaining decreases significantly with prolonged formalin fixation makes it necessary to exclude tumour tissue fixed in formalin for longer than 24 hours before processing. ${ }^{6.32}$ The marked heterogeneity in distribution of immunoreactivity would mean that the PCNA LI is also largely dependent on biopsy sampling and in a small biopsy the labelling may not be fully representative of the entire tumour. ${ }^{32}$ The heterogeneity in intensity of immunostaining could also lead to interpreting areas with low reactivity as negative areas thus introducing an element of subjectivity in interpretation. In an attempt to minimize the regional variability in PC10 we had quantitated those areas with highest concentration of positive immunostaining in all cases and used the values obtained for calculating the PCNA LI. Moreover, the regions with the highest proliferative activity in a tumour would be clinically most relevant to the patient's outcome in terms of the rate of growth, progression and spread to the tumour. Another drawback is observer bias that would occur with visual analysis of PCNA LI and this could preclude its routine use and furthermore it is very time consuming to count such large numbers of nuclei manually. In order to eliminate observer bias, a program using image analysis was designed for quantifying the PCNA LI in this study.

Previous studies on glioma, however have not yielded consensus on the correlation of PCNA expression with tumour grading. Louis et al. using the 19F4 monoclonal antibody against PCNA which is applicable only to cryostat sections have found that though the PCNA LI for higher grade (grade IV) tumours were appropriately high but it could not distinguish between the grade III and the lower grade tumours (i.e. grade I and II). ${ }^{14}$ Furthermore, they found that the $19 \mathrm{~F} 4$ antibody produced weaker and less consistent staining than $\mathrm{Ki}-67$ in cryostat sections. On the other hand using the PC10 Allegranza et al., ${ }^{15}$ Karamitopoulou et al. ${ }^{16}$ and Theunissen and Blaauw ${ }^{17}$ have found that the PCNA LI correlated well with the histological grades of astrocytoma. Only the last study ${ }^{17}$ has correlated the other clinical parameters such as survival, age at diagnosis and Karnofsky score to the PCNA immunoreactivity.

Our study demonstrates a significant correlation existed between PCNA LI and certain known prognostic factors for astrocytoma such as histological grade, age at the time of diagnosis and Karnofsky score. ${ }^{18}$ PCNA LI is also well correlated with the survival of tumour patients, with patients having PCNA $\mathrm{LI}$ of $6 \%$ or less showing significant better outcome than those with labelling index above $6 \%$. Because of the relatively small number of low grade astrocytomas and the short follow-up for some of them, we could not assess the value of PCNA LI in predicting which of these would remain as low grade tumours and which would progress to higher grades over a longer period. The univariate survival analysis using the Cox Proportional Hazard model has revealed that PCNA LI is less significant as a prognostic factor than histological grade. Furthermore, from the multivariate analysis we have concluded that PCNA LI is not an independent prognostic factor but it has derived its statistical association with survival secondarily through its relationship with tumour grade, age and Karnofsky score. Our findings support those of Theunissen and Blaauw ${ }^{17}$ in suggesting that while 
the PC10 immunoreactivity could be used as an additional method for assessing the prognosis of astrocytoma, it does not contribute any more reliable information on the outcome than histological grading based on the criteria of Daumas-Duport et al. $^{5}$

\section{ACKNOWLEDGEMENT}

The authors wish to thank Deanna Turetski, Mina Viscardi, Evangeline Weekes and Bob van den Beuken for preparation of manuscript and illustrations. We are also grateful to Ms. Serena Chiu for the assistance in the preparation of the graphs and tables.

\section{REFERENCES}

1. Kernohan JW, Sayre GP. Tumors of the central nervous system. In: Atlas of Tumor Pathology, Section 10, Vols 35 and 37. Washington: Armed Forces Institute of Pathology; 1952.

2. Kleihues P, Berger PC, Scheithauer BW. Histologic typing of tumours of the central nervous system. In: International Histologic Classification of Tumours. Geneva: World Health Organization; 1993; 11-14.

3. Burger PC, Vogel FS, Green SB, Strike TA. Glioblastoma multiforme and anaplastic astrocytoma. Cancer 1985; 56: 1106-1111.

4. Nelson JS, Tsukada Y, Schoenfeld D, et al. Necrosis as a prognostic criterion in malignant supratentorial, astrocytic gliomas. Cancer 1983; 52: 550-554.

5. Daumas-Duport C, Scheithauer B, O'Fallon J, Kelly P. Grading of astrocytomas, a simple and reproducible method. Cancer 1988; 62: 2152-2165.

6. Hall PA, Levison DA, Woods AL, et al. Proliferating cell nuclear antigen (PCNA) immunolocalization in paraffin sections: an index of cell proliferation with evidence of deregulated expression in some neoplasms. J Pathol 1990: 162: 285-294.

7. Bravo R, MacDonald-Bravo H. Existence of two populations of cyclin/proliferating cell nuclear antigen during the cell cycle: association with DNA replication sites. J Cell Biol 1987; 105: 1549-1554.

8. Bravo R, Frank R, Bludell PA, Macdonald-Bravo H. Cyclin/PCNA is the auxiliary protein of DNA polymerase- $\delta$. Nature $326: 515$.

9. Celis JE, Celis A. Cell cycle-dependent variations in the distribution of the nuclear protein cyclin, a proliferating cell nuclear antigen in cultured cells: subdivision of $S$ phase. Proc Natl Acad Sci USA, 1985: 82: 3262-3266.

10. Kurki P, Vanderlaan M, Dolbeare F, Gray J, Tan EM. Expression of proliferating cell nuclear antigen (PCNA)/cyclin during the cell cycle. Exp Cell Res 1986; 166: 209-219.

11. Jain S, Filipe MI, et al. Prognostic value of proliferating cell nuclear antigen in gastric carcinoma. J Clin Pathol 1991; 44: 655-659.

12. Woods AL, Hall PA, Shepherd NA, et al. The assessment of proliferating cell nuclear antigen (PCNA) immunostaining in primary gastrointestinal lymphomas and its relationship to histological grade, $S+G_{2}+M$ phase fraction (flow cytometric analysis) and prognosis. Histopathology 1991; 19: 21-27.

13. Yu CC-W, Fletcher CDM, Camplejohn RS, et al. Haemangio-pericytomas: the prognostic value of immunohistochemical staining with a monoclonal antibody to proliferating cell nuclear antigen (PCNA). Histopathology 1991; 19: 29-33.

14. Louis DN, Edgerton S, Thor AD, Hedley-Whyte ET. Proliferating cell nuclear antigen and $\mathrm{Ki}-67$ immunohistochemistry in brain tumors: a comparative study. Acta Neuropathol 1991; 81: 675679 .
15. Allegranza A, Girlando S, Arrigoni GL, et al. Proliferating cell nuclear antigen expression in central nervous system neoplasms. Virchows Archiv A Pathol Anat 1991; 419: 417-423.

16. Karamitopoulou E, Perentes E, Melachrinou M, Maraziotis T. Proliferating cell nuclear antigen immunoreactivity in human central nervous system neoplasms. Acta Neuropathol 1993; 85: 316-322.

17. Theunissen PHMH, Blaauw G. Proliferating cell nuclear antigen immunostaining and survival in cerebral astrocytoma. Histopathology 1993; 23:75-79

18. Byar DP, Green SB, Strike TA. Prognostic factors for malignant Glioma. In: Walker MD, ed. Oncology of the Nervous System. Boston/The Hague/Dordrecht/ Lancaster, Martinus Nijhoff Publishers, 1983: 379-395.

19. Morris GF, Mathews MB. Regulation of proliferating cell nuclear antigen during the cell cycle. J Biol Chem 1991;264: 1385613864.

20. Bravo $\mathrm{R}$, Macdonald-Bravo $\mathrm{H}$. Induction of the nuclear protein 'cyclin' in quiescent mouse 3T3 cells stimulated by serum and growth factors. Correlation with DNA synthesis. EMBO J 1984: 3; 3177-3181.

21. Jaskulski D, Gatti C, Travali S, Calabretta B, Baserga $R$. Regulation of the proliferating cell nuclear antigen cyclin and thymidine kinase mRNA levels by growth factors. J Biol Chem 1988; 263: 10175-10179.

22. Libermann TA, Razon N, Bartal AD, et al. Expression of epidermal growth factor receptors in human brain tumors. Cancer Res 1984: 753-760.

23. Gammeltoft S, Ballotti R, Kowalski A, Westermark B, Van Obberghen E. Expression of two types of receptor for insulinlike growth factors in human malignant glioma. Cancer Res 1988; 48: 1233-1237.

24. Nister M, Libermann TA, Betsholtz C, et al. Expression of messenger RNAs for platelet-derived growth factor and transforming growth factor- $\alpha$ and their receptor in human malignant glioma cell lines. Cancer Res 1988; 48: 3910-3918.

25. Reifenberger G, Prior R, Deckert M, Wechsler W. Epidermal growth factor receptor expression and growth fraction in human tumours of the nervous system. Virchows Archiv A Pathol Anat 1989; 414: 147-155.

26. Ito $\mathrm{M}$, Tsurusawa $\mathrm{M}, \mathrm{Z}$ ha $\mathrm{Z}$, et al. Cell proliferation in childhood acute leukemia. Cancer 1992; 69: 2176-2182.

27. Theunissen PHMH, Leers MPG, Bollen ECM. Proliferating cell nuclear antigen (PCNA) expression in formalin-fixed tissue of non-small cell lung carcinoma. Histopathology 1992; 20: 251255.

28. Galand P, Degraef C. Cyclin/PCNA immunostaining as an alternative to tritiated thymidine pulse labelling for marking $S$ phase cells in paraffin sections from animal and human tissues. Cell Tissue Kinet 1989; 22: 383-392.

29. Dervan PA, Magee HM, Buckley C, Carney DN. Proliferating cell nuclear antigen counts in formalin-fixed paraffin-embedded tissue correlate with $\mathrm{Ki}-67$ in fresh tissue. Am J Clin Pathol 1992; 97: (Suppl 1): S21-S28.

30. Kawakita N, Seki S, Yanai A, et al. Immunocytochemical identification of proliferative hepatocytes using monoclonal antibody to proliferating cell nuclear antigen (PCNA/cyclin). Am J Clin Pathol 1992; 97 (Suppl 1): S14-S20.

31. Smith FG, Murray PG, Crocker J. Correlation between PCNA and AgNOR scores in non-Hodgkin's lymphomas using sequential staining technique. J Clin Pathol 1993; 46: 28-31.

32. Linden MD, Torres FX, Kubus J, Zarbo RJ: Clinical application of morphologic and immunocytochemical assessments of cell proliferation. Am J Clin Pathol 1992; 97 (Suppl I): S4-S12. 